\title{
Comparative Effects of Weight Loss and Incretin-Based Therapies on Endothelial Vasodilatory and Fibrinolytic Function
}

Mona Mashayekhi, MD/PhD ${ }^{1}$; Joshua A. Beckman, MD, $\mathrm{MS}^{2}$; Hui Nian, $\mathrm{PhD}^{3}$; Erica M. Garner, $\mathrm{MD}^{1}$; Dustin Mayfield, APRN ${ }^{4}$; Patricia Wright, RN4; Sara E. Howard, BA ${ }^{4}$; Bradley Perkins, BA $^{5}$; Dianna Olson, RD, LDN ${ }^{6}$; William E. Snyder, III, MS ${ }^{7}$; Jessica K. Devin, MD/PhD ${ }^{8}$; John R. Koethe, MD ${ }^{9,10}$; Jonathan D. Brown, MD²; Katherine N. Cahill, MD ${ }^{7}$; Chang Yu, $\mathrm{PhD}^{3}$; Heidi Silver, $\mathrm{PhD}^{6,9}$; Kevin Niswender, MD/PhD ${ }^{9,1}$; James M. Luther, MD, MSCI ${ }^{4}$; Nancy J. Brown, $\mathrm{MD}^{11}$

${ }^{1}$ Vanderbilt University Medical Center, Department of Medicine, Division of Diabetes, Endocrinology and Metabolism, Nashville, TN

${ }^{2}$ Vanderbilt University Medical Center, Department of Medicine, Division of Cardiovascular Medicine, Nashville, TN

${ }^{3}$ Vanderbilt University Medical Center, Department of Biostatistics, Nashville, TN

${ }^{4}$ Vanderbilt University Medical Center, Department of Medicine, Division of Clinical Pharmacology, Nashville, TN

${ }^{5}$ Alabama College of Osteopathic Medicine, Dothon, AL

${ }^{6}$ Vanderbilt University Medical Center, Department of Medicine, Division of Gastroenterology, Nashville, TN

${ }^{7}$ Vanderbilt University Medical Center, Department of Medicine, Division of Allergy, Pulmonary and Critical Care Medicine, Nashville, TN

${ }^{8}$ UCHealth, Steamboat Springs, CO 
medRxiv preprint doi: https://doi.org/10.1101/2022.02.23.22271434; this version posted February 25, 2022. The copyright holder for this preprint

(which was not certified by peer review) is the author/funder, who has granted medRxiv a license to display the preprint in perpetuity.

All rights reserved. No reuse allowed without permission.

${ }^{9}$ Veterans Affairs Tennessee Valley Healthcare System, Nashville, TN

${ }^{10}$ Vanderbilt University Medical Center, Department of Medicine, Division of Infectious

Diseases, Nashville, TN

${ }^{11}$ Yale School of Medicine, New Haven, CT

Short Title: Vascular effects of diet or incretin-based drugs

\section{Corresponding Author:}

Nancy J. Brown, MD

Yale School of Medicine

Office of the Dean

333 Cedar Street

SHM C-203

New Haven, CT 06520

(203) 737-2841

nancy.j.brown@yale.edu

Total Word Count: 7,545 (include title page, abstract, text, references, tables, figure legends) 


\begin{abstract}
Background: Glucagon-like peptide-1 receptor (GLP1R) agonists decrease cardiovascular events in patients with type 2 diabetes, and cause weight loss regardless of diabetes status. The contribution of weight loss to the cardiovascular benefits of GLP1R agonists is unknown.

Methods: Obese pre-diabetic individuals were randomized to 14 weeks of the GLP1R agonist liraglutide, hypocaloric diet-mediated weight loss, or the dipeptidyl peptidase 4 inhibitor sitagliptin as an incretin-based drug comparator. Treatment with drug was double blind and placebo-controlled. Weight, metabolic and hemodynamic measures, endothelium-dependent vasodilation and fibrinolytic function were measured at baseline and after 2 and 14 weeks of treatment.
\end{abstract}

Results: Liraglutide and diet reduced weight, fasting blood glucose, and insulin resistance at 14 weeks, while sitagliptin did not. There was no significant effect of any treatment on endothelial vasodilatory function as measured by flow-mediated dilation (FMD). Because baseline endothelial function was normal in the overall cohort, post-hoc subgroup analyses were conducted in participants stratified by FMD below or above the median for gender. All three treatments improved FMD at 2 weeks in individuals with baseline endothelial dysfunction and sitagliptin and diet also improved endothelium-dependent vasodilation at 14 weeks. Liraglutide and diet reduced plasminogen activator inhibitor-1 (PAI-1) at 14 weeks. GLP1R antagonism with exendin (9-39) increased fasting blood glucose but did not change FMD or PAI-1 in the overall group. Exendin (9-39) attenuated the increase in FMD in the sitagliptin-treated group at two weeks.

Conclusions: Liraglutide and diet cause weight loss, improve insulin resistance and reduce PAI1 at 14 weeks. The effect on PAI-1 is GLP1R-independent. In individuals with low baseline 
medRxiv preprint doi: https://doi.org/10.1101/2022.02.23.22271434; this version posted February 25, 2022. The copyright holder for this preprint (which was not certified by peer review) is the author/funder, who has granted medRxiv a license to display the preprint in perpetuity. All rights reserved. No reuse allowed without permission.

FMD, sitagliptin and diet improve FMD at two and 14 weeks, while liraglutide improves FMD at two weeks.

Clinical Trial Registration: NCT03101930 https://clinicaltrials.gov/ct2/show/NCT03101930 
medRxiv preprint doi: https://doi.org/10.1101/2022.02.23.22271434; this version posted February 25, 2022. The copyright holder for this preprint

(which was not certified by peer review) is the author/funder, who has granted medRxiv a license to display the preprint in perpetuity.

All rights reserved. No reuse allowed without permission.

\section{Non-standard Abbreviations and Acronyms:}

DPP4: Dipeptidyl peptidase 4

FMD: Flow-mediated dilation

GLP-1: Glucagon-like peptide-1

GLP1R: Glucagon-like peptide-1 receptor

GLS: Generalized least squares

HbA1c: Hemoglobin A1c

HOMA-IR: Homeostatic Model Assessment for Insulin Resistance

HOMA2: Homeostatic Model Assessment 2

NMD: Nitroglycerin-mediated dilation

OGTT: Oral glucose tolerance test

PAI-1: Plasminogen activator inhibitor-1

T2DM: Type 2 diabetes mellitus

UACR: Urine albumin-to-creatinine ratio 


\section{Introduction}

Glucagon-like peptide-1 receptor (GLP1R) agonists decrease cardiovascular morbidity and mortality in patients with type 2 diabetes mellitus (T2DM). ${ }^{1-3}$ GLP1R agonists also cause significant weight loss and have been approved as pharmacologic weight loss therapy. ${ }^{4}$ Given that weight loss improves many of the risk factors for cardiovascular disease in patients with T2DM and insulin resistance, ${ }^{5,6}$ weight loss might contribute to the beneficial cardiovascular effects of the GLP1R agonists.

Dipeptidyl peptidase 4 (DPP4) inhibitors increase endogenous GLP-1 without inducing weight loss. DPP4 inhibitors have not been shown to reduce cardiovascular mortality in $\mathrm{T}_{2 \mathrm{DM}}{ }^{7,8}$ In addition to preventing the degradation of GLP-1, DPP4 inhibitors also prevent the degradation and formation of a variety of vasoactive peptides, rendering their properties less specific. $^{9}$

To understand the weight loss-independent effects of the GLP1R agonist liraglutide on vascular function, we compared the effects of the GLP1R agonist liraglutide to hypocaloric dietinduced weight loss and to treatment with the DPP4 inhibitor sitagliptin in a randomized controlled trial. We enrolled obese pre-diabetic individuals and measured weight, metabolic parameters, hemodynamic variables, endothelial function, and fibrinolysis after two weeks of therapy, before anticipated significant weight loss, and after 14 weeks of therapy. We evaluated endothelial function using flow-mediated vasodilation and assessed fibrinolysis by measuring plasminogen activator inhibitor-1 (PAI-1), the major inhibitor of tissue-type plasminogen activator in vivo. In addition, to assess whether the effects of treatment were GLP1R-dependent, we studied a subset of participants after treatment with the GLP1R antagonist exendin (9-39) and matching vehicle in a randomized, crossover design. 


\section{Methods}

\section{$\underline{\text { Participants }}$}

Men and women aged 18 to 65 years old with obesity $\left(\mathrm{BMI} \geq 30 \mathrm{~kg} / \mathrm{m}^{2}\right)$ and pre-diabetes were eligible for enrollment. Pre-diabetes was defined using the American Diabetes Association criteria as either impaired fasting glucose between 100-125 mg/dL or impaired glucose tolerance after a 75-gram glucose challenge of 140-199 mg/dL or hemoglobin A1c (HbA1C) 5.7-6.4\%. Pregnancy was excluded in women of child-bearing potential by urine $\beta$-human chorionic gonadotropin testing. Individuals with type 1 or type 2 diabetes, resistant hypertension, history of pancreatitis, significant cardiovascular disease, asthma with regular inhaler use, and impaired kidney or liver function were excluded. The study was approved by the Vanderbilt Institutional Review Board, registered at clinicaltrials.gov NCT03101930, and conducted according to the Declaration of Helsinki. All participants provided written informed consent.

\section{$\underline{\text { Protocol }}$}

Volunteers reported to the Vanderbilt Clinical Research Center to undergo screening. We obtained a medical history, completed a physical examination, and collected blood for measurement of HbA1C, complete blood count, basic metabolic panel, hepatic function panel, lipid profile, and collected urine for measurement of spot urine albumin-to-creatinine ratio (UACR). After an overnight fast, we performed a standard 75-gram oral glucose tolerance test with blood samples drawn at time 0, 30, 60, 90 and 120 minutes. We also measured resting energy expenditure (REE).

Eligible participants who chose to continue with the study underwent a six-week run-in 
phase to optimize their medical management (Supplemental Figure 1A and detailed methods in

Supplemental Materials). After the run-in phase, participants underwent a baseline study day during which we made anthropometric and hemodynamic measurements, measured flowmediated dilation (FMD), collected blood for measurement of glucose, insulin, PAI-1, and Pselectin (platelet function), collected urine for albumin and creatinine, and performed a mixedmeal study.

Participants were then randomized to liraglutide 1.8mg/day (Novo Nordisk), sitagliptin 100mg/day (Merck and Co, Inc), or hypocaloric diet in a 2:1:1 ratio, stratified by race.

Liraglutide was given on a dose escalation starting at $0.6 \mathrm{mg} /$ day for week $1,1.2 \mathrm{mg} /$ day for week 2 and then up to the full dose of $1.8 \mathrm{mg} /$ day at the start of week 3 . Treatment with liraglutide or sitagliptin was double blind and placebo-controlled, while treatment with diet was unblinded. Study drugs and placebo were a generous gift from Novo Nordisk.

Participants were treated for a total of 14 weeks. The first 74 participants underwent four study days. The first two study days were conducted after two weeks of treatment to measure the short-term effects of liraglutide, sitagliptin and diet. The first and second study days were separated by 48 hours and participants received a single dose infusion of placebo or the GLP1R antagonist exendin (9-39) on each day in random order to assess the contribution of GLP1R activation to any observed effects. The third and fourth study days were completed after 14 weeks to measure the effects of sustained liraglutide, sitagliptin and weight loss. The third and fourth study days were also separated by 48 hours and participants again received placebo or exendin (9-39) infusion in random order. The last 14 participants studied did not participate in the crossover aim with exendin (9-39) due to lack of drug availability, and only underwent two study days, one after two weeks of treatment and one after fourteen weeks of treatment. Placebo 
medRxiv preprint doi: https://doi.org/10.1101/2022.02.23.22271434; this version posted February 25, 2022. The copyright holder for this preprint (which was not certified by peer review) is the author/funder, who has granted medRxiv a license to display the preprint in perpetuity.

All rights reserved. No reuse allowed without permission.

vehicle was infused during each of these study days. All participants underwent repeat REE measurement and urine collection after 13.5 weeks of treatment at a separate visit to the Clinical Research Center.

\section{$\underline{\text { Study Day Protocol }}$}

Participants randomized to drug were called the night prior to each study day to ensure they had taken their subcutaneous injection. On the morning of each study day, participants arrived at the Clinical Research Center after an overnight fast. Those randomized to drug took their oral medication upon arrival (Supplemental Figure 1B). Participants then rested supine for 45 minutes, and we measured blood pressure and heart rate and collected blood for measurement of PAI-1 and P-selectin. After this rest period, participants were given placebo or the GLP1R antagonist exendin-(9-39) (Clinalfa ${ }^{\circledR}$, Bachem Distribution Services; Weil am Rhein, Germany; IND \#122,217) in randomized order on study days 1 and 2, and on study days 3 and 4. Exendin(9-39) was given as an IV bolus of $7500 \mathrm{pmol} / \mathrm{kg}$ over one minute followed by continuous infusion of $350 \mathrm{pmol} / \mathrm{kg} / \mathrm{min}$ for the remainder of the study. Infusion with placebo or exendin-(939) was double blind.

An hour after the start of the infusion, we measured FMD, then collected blood for measurement of PAI-1 and P-selectin, as well as fasting glucose and insulin. We then administered sublingual nitroglycerin $0.4 \mathrm{mg}$ for measurement of nitroglycerin-mediated vasodilation (NMD). After the FMD/NMD and approximately three hours following administration of oral study drug and 2 hours after start of infusion, participants ingested a standardized mixed-meal. 


\section{Measurement of Flow-Mediated Dilation}

Measurement of endothelium-dependent and endothelium-independent vasodilation was performed in a quiet, temperature-controlled $\left(23^{\circ} \mathrm{C}\right)$ room. Participants were asked to refrain from alcohol and caffeine for at least 12 hours prior to vascular function measurements. In addition, participants were asked to abstain from phosphodiesterase type 5 inhibitors for at least one week as these drugs may confound the measurement of vascular function or cause precipitous hypotension after nitroglycerin. Premenopausal women were studied during the same phase of the menstrual cycle at each visit to avoid variability of vascular function measures. FMD and NMD were measured as reported previously and detailed in Supplemental Materials. $^{10-13}$

\section{Hypocaloric Diet}

Participants in the hypocaloric diet arm were given a caloric goal designed to achieve a weight loss similar to that expected in the liraglutide treatment arm; based on prior studies of 1.8 $\mathrm{mg} / \mathrm{d}$ liraglutide this was predicted to be $\sim 0.27 \mathrm{~kg} /$ week. ${ }^{14-17}$ Each participant's caloric goal was determined by measuring REE at baseline and calculated to reduce total energy balance by 390 $\mathrm{kcal} / \mathrm{d} .{ }^{18}$ Participants were provided counseling and written instructions on how to achieve their daily caloric goal, including use of their own mobile phone applications to monitor caloric intake. To assure compliance with the prescribed caloric goal, participants met with the study dietitian every other week for problem solving and review of diet intake logs.

REE was measured in the supine position using a Parvo TrueOne 2400 portable metabolic system (ParvoMedics, Sandy, Utah) in a dimly lit, temperature-controlled room. A ventilated plexiglass hood was placed over the participant's head and connected to the metabolic 
cart by a single expired-gas hose. Indirect calorimetry was measured for 25-30 min, with the first 5-10 min eliminated from analysis. Before each use, the system was calibrated using room air and a single gas tank $\left(\sim 16 \% \mathrm{O}_{2}, 1 \% \mathrm{CO}_{2}\right)$. Whole-body rates of $\mathrm{O}_{2}$ consumption and $\mathrm{CO}_{2}$ production were determined from measurements of expired volume, and the differences in $\mathrm{O}_{2}$ and $\mathrm{CO}_{2}$ concentration between inspired and expired air. Ventilation was measured by a mass flow meter, oxygen concentration by a paramagnetic $\mathrm{O}_{2}$ analyzer, and $\mathrm{CO}_{2}$ by an infrared analyzer. REE was calculated from the Weir equation. ${ }^{19}$

Dietary recalls were performed by trained registered dietitians using the validated U.S.D.A. multi-pass recall method, a standardized script and software generated prompts. Intakes was analyzed for energy and nutrient content via Nutrition Data System (NDSR version 2016, U Minn) which automatically calculates average energy, macronutrients, micronutrients, nutrient ratios, food components and indices.

\section{$\underline{\text { Laboratory Analyses }}$}

A YSI glucose analyzer (YSI Life Sciences, Yellow Springs, OH) was used to measure plasma glucose immediately after collection. All remaining samples were stored at $-80^{\circ} \mathrm{C}$ in aliquots until the time of assay. Plasma insulin samples were collected in tubes containing aprotinin, and insulin was measured by radioimmunoassay (EMD Millipore, Billerica, MA). The assay cross-reacts with $38 \%$ intact proinsulin, but not with $\mathrm{C}$-peptide $(\leq 0.01 \%)$. Blood for PAI-1 was collected in $0.105 \mathrm{M}$ acidified sodium citrate and samples were analyzed using commercially available two-site ELISA using chromogenic substrates (TriniLIZE, Trinity Biotech, Berkeley Heights, NJ and American Diagnostica Inc, Stamford, CT). Serum samples for p-selectin were collected in a BD red top vacutainer tube, incubated at room temperature for 30 
medRxiv preprint doi: https://doi.org/10.1101/2022.02.23.22271434; this version posted February 25, 2022. The copyright holder for this preprint (which was not certified by peer review) is the author/funder, who has granted medRxiv a license to display the preprint in perpetuity.

All rights reserved. No reuse allowed without permission.

minutes, spun at 2,000 RPM for 10 minutes, then aliquoted for storage at -80C until measured by ELISA (R\&D Systems, Minneapolis, MN). Creatinine was measured using the Jaffe method. Urine albumin was measured by turbidimetric immunoassay with endpoint determination. HbA1C was measured using high pressure liquid chromatography (HPLC).

\section{$\underline{\text { Statistical Analyses }}$}

The primary endpoints were endothelial vascular function (FMD, UACR), and PAI-1, a marker of endothelial fibrinolytic function. Secondary endpoints reported here include blood pressure, heart rate, fasting insulin and glucose, and P-selectin as a marker of platelet function.

Descriptive statistics of patient baseline characteristics were presented as mean \pm SD for continuous variables and frequencies and proportions for categorical variables. Between-group comparison was performed using Kruskal-Wallis test or Pearson's chi-squared test. Withinsubject change in the endpoints at 2- and 14-week from baseline in each treatment group was tested using paired t-test. To evaluate the treatment effects on weight, fasting blood glucose, systolic blood pressure, diastolic blood pressure, heart rate and pre-infusion PAI-1 and Pselectin, separate multivariable generalized least squares (GLS) linear regression models were fitted using the data from vehicle-only study days. Treatment (liraglutide, sitagliptin or diet), time (2- or 14-week), baseline measurement as well as interaction between treatment and time were included as independent variables. A compound symmetry structure for within-subject correlation was used. For fasting blood glucose, fasting insulin, Homeostatic Model Assessment for Insulin Resistance (HOMA-IR), FMD percent and post-infusion PAI-1, GLS models were fitted using data from all study days. Treatment (liraglutide, sitagliptin or diet), infusion (vehicle or exendin (9-39)), time (2- or 14-week), baseline measurement as well as all the two-way and 
three-way interactions between treatment, time and infusion were included as independent variables. Inferences on the contrasts of interest was conducted using Wald test. All the analyses were performed using the statistical software $\mathrm{R} 4.1 .0 .^{20}$

We powered our study based on anticipated improvement in endothelial function. In studies of weight loss, improvement in endothelial function is proportionate to weight loss and the degree of weight loss achieved with liraglutide in the LEADER study has been associated with a $1.3 \% \pm 2.1 \%$ increase in brachial artery FMD. ${ }^{21}$ To detect a difference of $1.3 \% \pm 2.1 \%$ for within-individual comparisons, we had $79 \%$ power in the diet and sitagliptin arms $(\mathrm{N}=22)$, and $98 \%$ power in the liraglutide arm $(\mathrm{N}=44)$.

\section{Results}

\section{Participant characteristics}

Ninety-three individuals were randomized to treatment, with 46 to liraglutide, 23 to sitagliptin, and 24 to hypocaloric diet (Supplemental Figure 2). Three participants dropped out prior to receiving treatment, and two dropped out after receiving treatment but before completing any study days. Data from the remaining 88 individuals (44 randomized to liraglutide, 22 to sitagliptin, and 22 to hypocaloric diet) were analyzed. Seven individuals dropped out after completing study days 1 and 2 (two randomized to liraglutide, five to diet) and their available data were included in the analyses. Table 1 shows characteristics of the participants by treatment arm.

\section{Effect of treatment on weight and metabolic measures}

Liraglutide and diet caused weight loss, while sitagliptin did not (Figure 1A and Table 
2). Individuals in the diet arm lost significant weight from baseline at both 2 and 14 weeks (2 weeks: difference $-1.4 \mathrm{~kg}, 95 \%$ CI [-2.2, -0.6], $\mathrm{P}<0.01 ; 14$ weeks: $-5.0 \mathrm{~kg}[-7.0,-2.9], \mathrm{P}<0.001)$. Individuals in the liraglutide arm lost a small amount of weight from baseline to 2 weeks $(-0.5 \mathrm{~kg}$ $[-0.99,0.01], \mathrm{P}=0.05)$, and continued to lose weight by 14 weeks $(-2.7 \mathrm{~kg}[-3.8,-1.7], \mathrm{P}<0.001)$. Hypocaloric diet-treated participants lost more weight compared to liraglutide-treated participants at 14 weeks $(-2.3 \mathrm{~kg}[-3.7,-0.9], \mathrm{P}<0.01)$. In addition, both diet-treated and liraglutide-treated participants lost more weight than sitagliptin-treated participants at 14 weeks (liraglutide vs sitagliptin $-2.0 \mathrm{~kg}[-3.3,-0.6], \mathrm{P}<0.01$; diet vs sitagliptin $-4.2 \mathrm{~kg}[-5.8,-2.6]$, $\mathrm{P}<0.001)$.

Liraglutide and diet decreased HOMA-IR, a measure of insulin resistance, while sitagliptin did not (Figure 1B and Table 2). Diet caused the greatest decrease in HOMA-IR at both 2 and 14 weeks compared to baseline ( 2 weeks: -1.9 [-3.2, -0.6], P<0.01; 14 weeks: -2.3 [3.9, -0.6], $\mathrm{P}=0.01)$. Liraglutide also decreased HOMA-IR at both 2 and 14 weeks (2 weeks: -1.3 $[-2.2,-0.3], \mathrm{P}=0.01 ; 14$ weeks: $-1.2[-2.0,-0.3], \mathrm{P}=0.01)$. Both diet-treated and liraglutide-treated participants had a greater decrease in HOMA-IR than sitagliptin-treated participants at 14 weeks (liraglutide vs sitagliptin -1.6 [-3.1, -0.1$], \mathrm{P}=0.03$; diet vs sitagliptin $-2.3[-4.1,-0.5], \mathrm{P}=0.01$ ).

As shown in Figure 1C and Table 2, liraglutide and diet decreased fasting blood glucose, while sitagliptin did not. Liraglutide caused an early and sustained decrease in fasting blood glucose from baseline (2 weeks: $-10.8 \mathrm{mg} / \mathrm{dL}[-14.0,-7.7], \mathrm{P}<0.001 ; 14$ weeks: $-10.2 \mathrm{mg} / \mathrm{dL}$ [13.3, -7.2], $\mathrm{P}<0.001)$. Hypocaloric diet caused a small but significant decrease in fasting blood glucose by 14 weeks (2 weeks: $-2.1 \mathrm{mg} / \mathrm{dL}[-5.6,1.3], \mathrm{P}=0.22 ; 14$ weeks: $-3.0 \mathrm{mg} / \mathrm{dL}$ [-5.9, -0.1], $\mathrm{P}=0.04)$. Sitagliptin did not significantly alter fasting blood glucose at 2 or 14 weeks (2 weeks: $3.5 \mathrm{mg} / \mathrm{dL}[-6.9,0.01], \mathrm{P}=0.05 ; 14$ weeks: $-1.7 \mathrm{mg} / \mathrm{dL}[-5.2,1.8], \mathrm{P}=0.32)$. Liraglutide caused the 
greatest reduction in fasting glucose at 14 weeks (liraglutide vs sitagliptin $-9.2 \mathrm{mg} / \mathrm{dL}$ [-13.9, 4.5], $\mathrm{P}<0.001$; liraglutide vs diet $-6.9 \mathrm{mg} / \mathrm{dL}[-11.9,-2.0], \mathrm{P}<0.01)$.

Finally, as shown in Figure 1D and Table 2, diet decreased fasting insulin at both 2 and 14 weeks compared to baseline (2 weeks: $-7.0 \mu \mathrm{U} / \mathrm{mL}[-11.7,-2.2], \mathrm{P}<0.01 ; 14$ weeks: -7.5 $\mu \mathrm{U} / \mathrm{mL}[-13.0,-2.0], \mathrm{P}=0.01)$. Liraglutide tended to decrease fasting insulin, although this did not reach statistical significance ( 2 weeks: $-3.9 \mu \mathrm{U} / \mathrm{mL}[-8.0,0.2], \mathrm{P}=0.06 ; 14$ weeks: -3.1 $\mu \mathrm{U} / \mathrm{mL}[-7.0,0.9], \mathrm{P}=0.12)$. Sitagliptin did not alter fasting insulin at 2 or 14 weeks.

\section{Effect of treatment on resting hemodynamics}

Systolic blood pressure decreased significantly after hypocaloric diet (2 weeks: -6.1 mmHg [-9.5, -2.6], $\mathrm{P}<0.01 ; 14$ weeks: $-8.1 \mathrm{mmHg}[-13.8,-2.5], \mathrm{P}<0.01)$, but not with liraglutide or sitagliptin (Figure 2A). Diastolic blood pressure also decreased significantly after 14 weeks of hypocaloric diet (-3.8 mmHg [-7.4, -0.2], $\mathrm{P}=0.04)$ (Figure 2B). Liraglutide treatment increased heart rate at both 2 weeks $(+4.0 \mathrm{bpm}[2.3,5.8], \mathrm{P}<0.001)$ and 14 weeks $(+3.7 \mathrm{bpm}[1.5,5.9]$, $\mathrm{P}<0.01$; Figure 2C).

\section{Effect of treatment on endothelial vasodilatory function}

Baseline brachial artery diameter and FMD percent were comparable among treatment groups (Figure 3A and Table 2). Both liraglutide and sitagliptin tended to increase FMD as compared to baseline, however this increase did not reach statistical significance for either drug alone (Liraglutide 2 weeks: $+0.7 \%[-0.9,2.3], \mathrm{P}=0.36 ; 14$ weeks: $+1.4 \%[-0.3,3.1], \mathrm{P}=0.10$ Sitagliptin 2 weeks: $+2.1 \%[-0.9,5.1], \mathrm{P}=0.17 ; 14$ weeks: $+1.6 \%[-1.0,4.1], \mathrm{P}=0.21)$. There was neither effect nor trend for hypocaloric diet on FMD at either $2(+1.2 \%[-1.1,3.6], \mathrm{P}=0.28)$ or 14 
weeks $(+1.0 \%[-1.9,3.9], \mathrm{P}=0.46)$. There was no significant change in endothelium-independent NMD in any of the treatment groups (Table 2).

In considering the cohort's clinical characteristics, we noted that baseline endothelial function was similar to our past work in healthy subjects. ${ }^{12,22}$ In a post-hoc exploratory analysis, we divided the cohort into those with baseline FMD below or above the median for gender, to query the effect of treatment in individuals with normal and reduced baseline endothelial function. Baseline characteristics of these subgroups are shown in Table 3. Three individuals were missing baseline FMD and were excluded from this analysis. Individuals with lower baseline FMD had increased BMI, waist circumference, fasting insulin and insulin resistance as measured by HOMA-IR and HOMA2 compared to those with higher baseline FMD. As shown in Figure 3B, in individuals with lower baseline FMD, treatment with liraglutide, sitagliptin and hypocaloric diet improved FMD after 2 weeks. This effect remained significant in the sitagliptin and diet groups at 14 weeks. Of note, FMD in individuals with normal baseline FMD did not change with any intervention (Figure 3C).

Urine albumin-to-creatinine ratio, which is associated with vascular endothelial function and is a predictor of cardiovascular events, ${ }^{23-25}$ was not changed by treatment (Table 2).

\section{Effect of treatment on fibrinolysis}

We evaluated endothelial fibrinolytic balance by measuring PAI-1 concentration. Liraglutide and hypocaloric diet significantly decreased PAI-1 concentration from baseline to 14 weeks of treatment (liraglutide: $-3.7 \mathrm{U} / \mathrm{mL}[-6.5,-1.0], \mathrm{P}<0.01$; diet: $-3.6 \mathrm{U} / \mathrm{mL}[-7.1,-0.1]$, $\mathrm{P}<0.05$; Figure 4) but not at 2 weeks. Sitagliptin treatment did not affect PAI-1 concentration. In addition, PAI-1 levels were lower at 14 weeks in both the liraglutide- and diet-treated individuals 
compared to sitagliptin (liraglutide vs sitagliptin: $-3.7 \mathrm{U} / \mathrm{mL}[-6.7,-0.6], \mathrm{P}=0.02$; diet vs sitagliptin: $-4.8 \mathrm{U} / \mathrm{mL}[-8.5,-1.1], \mathrm{P}=0.01)$. P-selectin, a marker of platelet and endothelial activation, was unchanged by treatment (Table 2 ).

\section{Effect of GLP1R antagonism}

To test the hypothesis that GLP1R activation contributes to the acute or sustained effects of liraglutide or sitagliptin, we compared the effect of pretreatment with the GLP1R antagonist exendin (9-39) and vehicle on effects of treatment at 2 and 14 weeks. As shown in Figure 5A, GLP1R antagonism with exendin (9-39) raised fasting blood glucose in all treatment groups at both 2 and 14 weeks. Overall, exendin did not change FMD in liraglutide, sitagliptin, or diettreated participants (Figure 5B). In the stratified analysis of those with below-median FMD, exendin decreased FMD in sitagliptin-treated individuals at 2 weeks $(-3.6[-6.8,-0.4], \mathrm{P}=0.03)$, but not at 14 weeks $(-0.4[-3.6,2.8], \mathrm{P}=0.82)$ as compared to vehicle. Finally, there was no effect of GLP1R antagonism on PAI-1 concentrations in any treatment group (data not shown).

\section{Discussion}

GLP1R agonists reduce major adverse cardiovascular outcomes in T2DM and cause weight loss in obese individuals. We performed a randomized controlled study comparing the effects of treatment with a GLP1R agonist, hypocaloric diet-induced weight loss, and a DPP4 inhibitor in obese pre-diabetic individuals. Our aim was to dissect the weight loss-dependent and -independent effects of GLP1R agonist treatment on intermediate measures of cardiovascular disease. We found no effect of liraglutide, diet-induced weight loss, or sitagliptin on endothelium-dependent vasodilation as measured by FMD in the overall cohort. In a post-hoc 
exploratory analysis, liraglutide, weight loss, and sitagliptin all improved endothelial function in those individuals with baseline FMD below the median of our cohort after 2 weeks, and this effect remained significant in the sitagliptin and weight loss groups at 14 weeks. In contrast, liraglutide treatment and weight loss, but not sitagliptin treatment, significantly reduced PAI-1 after 14 weeks, and GLP1R antagonism did not alter this effect.

Prior studies of the effects of GLP1R agonists on endothelial function as measured by FMD were all performed in individuals with T2DM and demonstrated mixed results. Two studies found no effect, ${ }^{26,27}$ three reported improvement in FMD, ${ }^{28-30}$ and a systematic review and meta-analysis did not find a significant effect of GLP1R agonists on FMD. Interpretation of these data are limited by the modest number of and heterogeneity between published studies. ${ }^{31}$ Our study is the largest evaluating the effect of GLP1R agonist treatment on FMD to date, and the first study that is controlled and blinded (to drug assignment). Notably, our overall cohort demonstrated intact endothelium-dependent vasodilation compared to participants in prior studies, with a median FMD 9.91\% compared to values ranging from 1.6-8.9\% in prior studies. We anticipated FMD to be better in individuals with pre-diabetes as compared to those with type 2 diabetes at the outset. However, our recruitment created a group with FMD similar to a healthy group, not one with pre-diabetes. ${ }^{12}$ Our exploratory analysis supports the hypothesis that liraglutide may improve FMD in obese individuals with prediabetes and attenuated baseline FMD. This work also shows that improvements beyond normal do not occur, as we have shown previously. ${ }^{32}$

We assessed the on-target effects of GLP1R activation by measuring the impact of cotreatment with the GLP1R antagonist exendin (9-39). GLP1R inhibition significantly increased fasting glucose at 2 and 14 weeks in all treatment groups. This effect of exendin on fasting 
glucose has been demonstrated previously. ${ }^{33,34}$ GLP1R antagonism did not change FMD percent or PAI-1 measurements in the overall cohort. Exendin attenuated FMD after 2 weeks of treatment with sitagliptin in the subgroup of individuals with lower baseline endothelial function, suggesting that increased endogenous GLP-1 contributed to improved endothelium-dependent vasodilation during early sitagliptin treatment in this group.

PAI-1 is the primary inhibitor of tissue plasminogen activator and is central to regulating fibrinolysis. PAI-1 is increased in obese ${ }^{35}$ and insulin resistant individuals, ${ }^{36-38}$ and PAI-1 levels predict incident myocardial infarction. ${ }^{39} \mathrm{PAI}-1$ expression is upregulated by inflammatory stimuli such as interleukin-6 and tumor necrosis factor-alpha, as well as by metabolic stimuli including hyperglycemia, hyperinsulinemia, and elevated VLDL. ${ }^{38}$ PAI-1 has been found to decrease after weight loss ${ }^{40}$ or treatment with GLP1R agonists. ${ }^{41,42}$ Three pieces of evidence suggest that improvements in PAI-1 are mediated by reductions in weight and coincident improvements in dysmetabolism. First, PAI-1 decreased with both liraglutide treatment and hypocaloric diet only after clinically significant weight loss at 14 weeks. Second, HOMA-IR decreased in these two groups, but not in the sitagliptin-treated group. Third, exendin (9-39), a GLP1R antagonist, had no effect on PAI-1. These data support the notion that the decrease in PAI-1 after GLP1R agonist treatment is mediated by weight loss and improvement in insulin resistance, rather than a receptor-specific effect.

Weight loss in the hypocaloric diet group was associated with a significant decline in systolic blood pressure over 14 weeks, whereas there was no decrease in systolic blood pressure in either the sitagliptin or liraglutide group. Weight loss was significantly less in the liraglutidetreated group compared to in the hypocaloric diet-treated, and stimulation of the sympathetic nervous system may have counteracted any favorable effect of weight loss on systolic blood 
pressure in the liraglutide-treated group. Activation of GLP-1 receptors in the hypothalamus and brainstem by long-acting GLP1R agonists stimulate sympathetic outflow. ${ }^{43}$ Increased heart rate, observed in the liraglutide-treated group, is a hallmark of treatment with stable GLP1R agonists. ${ }^{44}$ Interestingly, treatment with sitagliptin did not increase heart rate. We have previously reported that heart rate is increased after short-term treatment with sitagliptin and ACE inhibition, ${ }^{45,46}$ but not after longer duration treatment, ${ }^{47}$ even though norepinephrine concentrations are increased. Decreased degradation of substance P may contribute to sympathetic stimulation when both DPP4 and ACE are inhibited. In the present study, a minority of participants were taking concurrent anti-hypertensive medications.

This study has several limitations. The majority of participants enrolled were women. The study was not powered to permit comparison between effects in men and women. In addition, we enrolled individuals with pre-diabetes rather than overt diabetes, which may have diminished the effect size of our treatment by eliminating the hyperglycemia component of vascular dysfunction. ${ }^{48}$ We chose to study obese pre-diabetic individuals to study a homogenous population with baseline insulin resistance but without overt hyperglycemia so as to avoid confounding by concurrent anti-diabetic medications or by varying severity and duration of diabetes. As noted, the participants had normal baseline endothelium-dependent vasodilation. We completed a post-hoc analysis stratified by baseline FMD below and above the median. Although not pre-specified, the finding that those with lower baseline FMD were significantly more insulin resistant than those with higher baseline FMD provides physiologic support of the analysis.

In conclusion, in the largest study of the effect of a GLP1R agonist on brachial artery endothelium-dependent vasodilation, liraglutide, sitagliptin, and weight loss had no effect in 
obese pre-diabetic individuals with normal baseline endothelial function. Liraglutide and sitagliptin both improved FMD in those individuals with below-median FMD and the effect of sitagliptin was attenuated by a GLP1R antagonist at 2 weeks. Weight loss, whether due to liraglutide therapy or hypocaloric diet, decreased PAI-1 through a GLP1R-independent mechanism. Future studies exploring alternate mechanisms for the cardiovascular benefits of GLP1R agonists, such as reductions in vascular inflammation, are needed. ${ }^{49}$ 


\section{Acknowledgements}

The authors acknowledge contributions from Anthony Dematteo.

\section{Sources of Funding}

Research reported in this publication was supported by the American Heart Association 17SFRN33520017 (M.M., J.A.B., H.N., D.M., P.W., S.E.H., B.P., D.O., J.R.K., C.Y., H.S.,

J.M.L, N.J.B), National Center for Advancing Translational Sciences 5UL1TR002243, National Institute of Diabetes and Digestive and Kidney Diseases T32DK007061 (M.M), National Institute of Allergy and Infectious Diseases U19AI095227 (K.N.C), National Heart, Lung and Blood Instituted R01HL146654 (J.D.B). This work utilized the core(s) of the Vanderbilt

Diabetes Research and Training Center funded by grant DK020593 from the National Institute of Diabetes and Digestive and Kidney Disease. Novo Nordisk provided liraglutide and matching placebo.

\section{Disclosures}

None unless noted below:

J.A.B.: Dr. Beckman is a consultant for JanOne, serves on a DSMB for Janssen and Novartis, and has ownership in EMX and Janacare.

J.R.K: Dr. Koethe has served as a consultant to Gilead Sciences, Merck, ViiV Healthcare, Theratechnologies and Janssen. He has also received research support from Gilead Sciences and Merck.

N.J.B.: Dr. Brown serves on the scientific advisory board for Alnylam Pharmaceuticals. She serves as a consultant for Pharvaris Gmbh. 
medRxiv preprint doi: https://doi.org/10.1101/2022.02.23.22271434; this version posted February 25, 2022. The copyright holder for this preprint (which was not certified by peer review) is the author/funder, who has granted medRxiv a license to display the preprint in perpetuity.

All rights reserved. No reuse allowed without permission.

\section{References}

1. Marso SP, Daniels GH, Brown-Frandsen K, et al. Liraglutide and Cardiovascular Outcomes in Type 2 Diabetes. N Engl J Med. 2016;375(4):311-322.

2. Sattar N, Lee MMY, Kristensen SL, et al. Cardiovascular, mortality, and kidney outcomes with GLP-1 receptor agonists in patients with type 2 diabetes: a systematic review and meta-analysis of randomised trials. Lancet Diabetes Endocrinol. $2021 ; 9(10): 653-662$.

3. Nauck MA, Quast DR, Wefers J, Meier JJ. GLP-1 receptor agonists in the treatment of type 2 diabetes - state-of-the-art. Mol Metab. 2021;46:101102.

4. Astrup A, Carraro R, Finer N, et al. Safety, tolerability and sustained weight loss over 2 years with the once-daily human GLP-1 analog, liraglutide. Int $J$ Obes (Lond). 2012;36(6):843-854.

5. Look ARG, Gregg EW, Jakicic JM, et al. Association of the magnitude of weight loss and changes in physical fitness with long-term cardiovascular disease outcomes in overweight or obese people with type 2 diabetes: a post-hoc analysis of the Look AHEAD randomised clinical trial. Lancet Diabetes Endocrinol. 2016;4(11):913-921.

6. Joris PJ, Zeegers MP, Mensink RP. Weight loss improves fasting flow-mediated vasodilation in adults: a meta-analysis of intervention studies. Atherosclerosis. 2015;239(1):21-30.

7. Zheng SL, Roddick AJ, Aghar-Jaffar R, et al. Association Between Use of SodiumGlucose Cotransporter 2 Inhibitors, Glucagon-like Peptide 1 Agonists, and Dipeptidyl Peptidase 4 Inhibitors With All-Cause Mortality in Patients With Type 2 Diabetes: A Systematic Review and Meta-analysis. JAMA. 2018;319(15):1580-1591.

8. Green JB, Bethel MA, Armstrong PW, et al. Effect of Sitagliptin on Cardiovascular Outcomes in Type 2 Diabetes. N Engl J Med. 2015;373(3):232-242.

9. Wilson JR, Kerman SJ, Hubers SA, et al. Dipeptidyl Peptidase 4 Inhibition Increases Postprandial Norepinephrine via Substance P (NK1 Receptor) During RAAS Inhibition. J Endocr Soc. 2019;3(10):1784-1798.

10. Beckman JA, Goldfine AB, Dunaif A, Gerhard-Herman M, Creager MA. Endothelial function varies according to insulin resistance disease type. Diabetes Care. 2007;30(5):1226-1232.

11. Owens CD, Wake N, Conte MS, Gerhard-Herman M, Beckman JA. In vivo human lower extremity saphenous vein bypass grafts manifest flow mediated vasodilation. $J$ Vasc Surg. 2009;50(5):1063-1070.

12. Nohria A, Kinlay S, Buck JS, et al. The effect of salsalate therapy on endothelial function in a broad range of subjects. J Am Heart Assoc. 2014;3(1):e000609.

13. Nguyen PL, Jarolim P, Basaria S, et al. Androgen deprivation therapy reversibly increases endothelium-dependent vasodilation in men with prostate cancer. J Am Heart Assoc. 2015;4(4).

14. Davies MJ, Bergenstal R, Bode B, et al. Efficacy of liraglutide for weight loss among patients with type 2 diabetes: The scale diabetes randomized clinical trial. JAMA. 2015;314(7):687-699.

15. Nauck M, Rizzo M, Johnson A, Bosch-Traberg H, Madsen J, Cariou B. Once-Daily Liraglutide Versus Lixisenatide as Add-on to Metformin in Type 2 Diabetes: A 26-Week Randomized Controlled Clinical Trial. Diabetes Care. 2016;39(9):1501-1509.

16. Lingvay I, Perez Manghi F, Garcia-Hernandez P, et al. Effect of Insulin Glargine Uptitration vs Insulin Degludec/Liraglutide on Glycated Hemoglobin Levels in Patients With Uncontrolled Type 2 Diabetes: The DUAL V Randomized Clinical Trial. JAMA. 
medRxiv preprint doi: https://doi.org/10.1101/2022.02.23.22271434; this version posted February 25, 2022. The copyright holder for this preprint (which was not certified by peer review) is the author/funder, who has granted medRxiv a license to display the preprint in perpetuity. All rights reserved. No reuse allowed without permission.

2016;315(9):898-907.

17. Bailey TS, Takacs R, Tinahones FJ, et al. Efficacy and safety of switching from sitagliptin to liraglutide in subjects with type 2 diabetes (LIRA-SWITCH): a randomized, double-blind, double-dummy, active-controlled 26-week trial. Diabetes Obes Metab. 2016.

18. Schoeller DA, Buchholz AC. Energetics of obesity and weight control: does diet composition matter? J Am Diet Assoc. 2005;105(5 Suppl 1):S24-28.

19. Mansell PI, Macdonald IA. Reappraisal of the Weir equation for calculation of metabolic rate. Am J Physiol. 1990;258(6 Pt 2):R1347-1354.

20. $R$ : A language and environment for statistical computing [computer program]. Vienna, Austria: R Foundation for Statistical Computing; 2021.

21. Ades PA, Savage PD, Lischke $S$, et al. The effect of weight loss and exercise training on flow-mediated dilatation in coronary heart disease: a randomized trial. Chest. 2011;140(6):1420-1427.

22. Beckman JA, Hu JR, Huang S, et al. Metabolomics reveals the impact of Type 2 diabetes on local muscle and vascular responses to ischemic stress. Clin Sci (Lond). 2020;134(17):2369-2379.

23. Chronic Kidney Disease Prognosis C, Matsushita K, van der Velde M, et al. Association of estimated glomerular filtration rate and albuminuria with all-cause and cardiovascular mortality in general population cohorts: a collaborative meta-analysis. Lancet. 2010;375(9731):2073-2081.

24. Hallan S, Astor B, Romundstad S, Aasarod K, Kvenild K, Coresh J. Association of kidney function and albuminuria with cardiovascular mortality in older vs younger individuals: The HUNT II Study. Arch Intern Med. 2007;167(22):2490-2496.

25. Astor BC, Hallan SI, Miller ER, 3rd, Yeung E, Coresh J. Glomerular filtration rate, albuminuria, and risk of cardiovascular and all-cause mortality in the US population. Am J Epidemiol. 2008;167(10):1226-1234.

26. Nomoto H, Miyoshi H, Furumoto T, et al. A Comparison of the Effects of the GLP-1 Analogue Liraglutide and Insulin Glargine on Endothelial Function and Metabolic Parameters: A Randomized, Controlled Trial Sapporo Athero-Incretin Study 2 (SAIS2). PLoS One. 2015;10(8):e0135854.

27. Hopkins ND, Cuthbertson DJ, Kemp GJ, et al. Effects of 6 months glucagon-like peptide1 receptor agonist treatment on endothelial function in type 2 diabetes mellitus patients. Diabetes Obes Metab. 2013;15(8):770-773.

28. Irace C, De Luca S, Shehaj E, et al. Exenatide improves endothelial function assessed by flow mediated dilation technique in subjects with type 2 diabetes: results from an observational research. Diab Vasc Dis Res. 2013;10(1):72-77.

29. Lambadiari V, Pavlidis G, Kousathana F, et al. Effects of 6-month treatment with the glucagon like peptide-1 analogue liraglutide on arterial stiffness, left ventricular myocardial deformation and oxidative stress in subjects with newly diagnosed type 2 diabetes. Cardiovasc Diabetol. 2018;17(1):8.

30. Gurkan E, Tarkun I, Sahin T, Cetinarslan B, Canturk Z. Evaluation of exenatide versus insulin glargine for the impact on endothelial functions and cardiovascular risk markers. Diabetes Res Clin Pract. 2014;106(3):567-575.

31. Batzias K, Antonopoulos AS, Oikonomou E, et al. Effects of Newer Antidiabetic Drugs on Endothelial Function and Arterial Stiffness: A Systematic Review and Meta-Analysis. J Diabetes Res. 2018;2018:1232583.

32. Beckman JA, Liao JK, Hurley S, et al. Atorvastatin restores endothelial function in normocholesterolemic smokers independent of changes in low-density lipoprotein. Circ 
medRxiv preprint doi: https://doi.org/10.1101/2022.02.23.22271434; this version posted February 25, 2022. The copyright holder for this preprint (which was not certified by peer review) is the author/funder, who has granted medRxiv a license to display the preprint in perpetuity.

All rights reserved. No reuse allowed without permission.

Res. 2004;95(2):217-223.

33. Schirra J, Nicolaus M, Roggel R, et al. Endogenous glucagon-like peptide 1 controls endocrine pancreatic secretion and antro-pyloro-duodenal motility in humans. Gut. 2006;55(2):243-251.

34. Edwards CM, Todd JF, Mahmoudi M, et al. Glucagon-like peptide 1 has a physiological role in the control of postprandial glucose in humans: studies with the antagonist exendin 9-39. Diabetes. 1999;48(1):86-93.

35. Orenes-Pinero E, Pineda J, Roldan V, et al. Effects of Body Mass Index on the Lipid Profile and Biomarkers of Inflammation and a Fibrinolytic and Prothrombotic State. $J$ Atheroscler Thromb. 2015;22(6):610-617.

36. Vague P, Juhan-Vague I, Aillaud MF, et al. Correlation between blood fibrinolytic activity, plasminogen activator inhibitor level, plasma insulin level, and relative body weight in normal and obese subjects. Metabolism. 1986;35(3):250-253.

37. Juhan-Vague I, Alessi MC, Vague P. Increased plasma plasminogen activator inhibitor 1 levels. A possible link between insulin resistance and atherothrombosis. Diabetologia. $1991 ; 34(7): 457-462$.

38. Brown NJ. Therapeutic potential of plasminogen activator inhibitor-1 inhibitors. Ther Adv Cardiovasc Dis. 2010;4(5):315-324.

39. Thogersen AM, Jansson $\mathrm{JH}$, Boman $\mathrm{K}$, et al. High plasminogen activator inhibitor and tissue plasminogen activator levels in plasma precede a first acute myocardial infarction in both men and women: evidence for the fibrinolytic system as an independent primary risk factor. Circulation. 1998;98(21):2241-2247.

40. Folsom AR, Qamhieh HT, Wing RR, et al. Impact of weight loss on plasminogen activator inhibitor (PAl-1), factor VII, and other hemostatic factors in moderately overweight adults. Arterioscler Thromb. 1993;13(2):162-169.

41. Courreges JP, Vilsboll T, Zdravkovic M, et al. Beneficial effects of once-daily liraglutide, a human glucagon-like peptide-1 analogue, on cardiovascular risk biomarkers in patients with Type 2 diabetes. Diabet Med. 2008;25(9):1129-1131.

42. Forst T, Michelson G, Ratter F, et al. Addition of liraglutide in patients with Type 2 diabetes well controlled on metformin monotherapy improves several markers of vascular function. Diabet Med. 2012;29(9):1115-1118.

43. Yamamoto H, Lee CE, Marcus JN, et al. Glucagon-like peptide-1 receptor stimulation increases blood pressure and heart rate and activates autonomic regulatory neurons. $J$ Clin Invest. 2002;110(1):43-52.

44. Sun F, Wu S, Guo S, et al. Impact of GLP-1 receptor agonists on blood pressure, heart rate and hypertension among patients with type 2 diabetes: A systematic review and network meta-analysis. Diabetes Res Clin Pract. 2015;110(1):26-37.

45. Devin JK, Pretorius M, Nian H, Yu C, Billings FTt, Brown NJ. Substance P increases sympathetic activity during combined angiotensin-converting enzyme and dipeptidyl peptidase-4 inhibition. Hypertension. 2014;63(5):951-957.

46. Marney A, Kunchakarra S, Byrne L, Brown NJ. Interactive hemodynamic effects of dipeptidyl peptidase-IV inhibition and angiotensin-converting enzyme inhibition in humans. Hypertension. 2010;56(4):728-733.

47. Wilson JR, Garner EM, Mashayekhi M, et al. DPP4 (Dipeptidyl Peptidase-4) Inhibition Increases Catecholamines Without Increasing Blood Pressure During Sustained ACE (Angiotensin-Converting Enzyme) Inhibitor Treatment. Hypertension. 2022:HYPERTENSIONAHA12118348.

48. Beckman JA, Goldfine AB, Gordon MB, Creager MA. Ascorbate restores endotheliumdependent vasodilation impaired by acute hyperglycemia in humans. Circulation. 
medRxiv preprint doi: https://doi.org/10.1101/2022.02.23.22271434; this version posted February 25, 2022. The copyright holder for this preprint

(which was not certified by peer review) is the author/funder, who has granted medRxiv a license to display the preprint in perpetuity.

All rights reserved. No reuse allowed without permission.

$2001 ; 103(12): 1618-1623$.

49. Lee MMY, Petrie MC, McMurray JJV, Sattar N. How Do SGLT2 (Sodium-Glucose Cotransporter 2) Inhibitors and GLP-1 (Glucagon-Like Peptide-1) Receptor Agonists Reduce Cardiovascular Outcomes?: Completed and Ongoing Mechanistic Trials. Arterioscler Thromb Vasc Biol. 2020;40(3):506-522. 
medRxiv preprint doi: https://doi.org/10.1101/2022.02.23.22271434; this version posted February 25, 2022. The copyright holder for this preprint (which was not certified by peer review) is the author/funder, who has granted medRxiv a license to display the preprint in perpetuity. All rights reserved. No reuse allowed without permission.

Tables and Diagrams

Table 1. Baseline Characteristics

\section{Liraglutide Sitagliptin Diet Combined}

Age, years

$\mathrm{N}=44 \quad \mathrm{~N}=22 \quad \mathrm{~N}=22 \quad \mathrm{~N}=88$

Gender

Male

$31.8 \%(7)$

$36.4 \%(8)$

$31.8 \%(28)$

Female

$70.5 \%(31)$

$68.2 \%(15)$

$63.6 \%(14)$

$68.2 \%(60)$

Race
Asian
$4.5 \%(2)$
$0 \%(0)$
$0 \%(0)$
$2.3 \%(2)$
Black or African American
$9.1 \%(4)$
$13.6 \%(3)$
$18.2 \%(4)$
$12.5 \%(11)$
White
$86.4 \%(38)$
$81.8 \%(18)$
$77.3 \%(17)$
$83.0 \%(73)$
More Than One Race
$0 \%(0)$
$4.5 \%(1)$
$4.5 \%(1)$
$2.3 \%(2)$

Ethnicity

Hispanic or Latino

$$
2.3 \%(1)
$$

$$
9.1 \%(2)
$$

$4.5 \%(1)$

$4.5 \%(4)$

NOT Hispanic or Latino

$95.5 \%(42) \quad 90.9 \%(20) \quad 95.5 \%(21) \quad 94.3 \%(83)$

Unknown / Not Reported

$$
2.3 \%(1)
$$

$0 \%(0)$

$0 \%(0)$

$1.1 \%(1)$

Weight, kg

$108.8 \pm 20.9 \quad 111.4 \pm 22.0 \quad 111.3 \pm 21.5 \quad 110.1 \pm 21.1$

BMI, $\mathrm{kg} / \mathrm{m}^{2}$

$38.8 \pm 6.1$

$39.9 \pm 6.0$

$38.4 \pm 5.9$

$39.0 \pm 6.0$

Waist Circumference, $\mathrm{cm}$

$115.8 \pm 11.5$

$118.4 \pm 14.5$

$117.5 \pm 13.6$

$116.9 \pm 12.8$

Hip Circumference, cm

$126.2 \pm 12.7$

$126.2 \pm 12.0$

$125.7 \pm 10.9$

$126.1 \pm 11.9$

Fasting blood glucose, $\mathrm{mg} / \mathrm{dL}$

$$
96.2 \pm 10.1
$$

$100.2 \pm 9.4$

$96.7 \pm 11.8$

$97.4 \pm 10.4$

Fasting insulin, $\mu \mathrm{U} / \mathrm{mL}$

$21.4 \pm 13.9$

$26.9 \pm 14.0$

$18.4 \pm 7.4$

$22.3 \pm 12.8$

OGTT 2-hour blood glucose, mg/dL

$142.0 \pm 24.8$

$148.1 \pm 41.1$

$130.2 \pm 27.8$

$140.6 \pm 30.7$

HOMA-IR

$5.0 \pm 3.0$

$6.5 \pm 3.3$

$4.6 \pm 2.4$

$5.3 \pm 3.0$ 
medRxiv preprint doi: https://doi.org/10.1101/2022.02.23.22271434; this version posted February 25, 2022. The copyright holder for this preprint (which was not certified by peer review) is the author/funder, who has granted medRxiv a license to display the preprint in perpetuity. All rights reserved. No reuse allowed without permission.

HOMA2

Hemoglobin A1c, \%

Total cholesterol, $\mathrm{mg} / \mathrm{dL}$

Triglycerides, $\mathrm{mg} / \mathrm{dL}$

$\mathrm{HDL}, \mathrm{mg} / \mathrm{dL}$

LDL, mg/dL

Systolic blood pressure, $\mathrm{mmHg}$

Diastolic blood pressure, $\mathrm{mmHg}$

Heart rate, bpm

Anti-hypertensive agent use

FMD, \%

$$
0.41 \pm 0.25
$$$$
5.7 \pm 0.3
$$$$
191.0 \pm 39.2
$$

$122.2 \pm 51.4$

$143.3 \pm 59.6$

$115.0 \pm 67.1$

$125.9 \pm 58.0$

$$
47.5 \pm 9.6
$$

$119.1 \pm 31.9$

$45.6 \pm 11.2$

$44.1 \pm 10.9$

$46.2 \pm 10.3$

$118.2 \pm 27.0$

$111.5 \pm 35.7$

$117.0 \pm 31.4$

124.1 \pm 7.7

$120.2 \pm 11.3^{*}$

$127.7 \pm 8.3$

$124.1 \pm 9.1$

$77.6 \pm 9.3$

$74.7 \pm 8.7$

$77.8 \pm 7.0$

$76.9 \pm 8.6$

$64.9 \pm 7.4$

$67.2 \pm 9.0$

$63.8 \pm 8.8$

$65.2 \pm 8.2$

$25.0 \%(11)$

$36.4 \%(8)$

$45.5 \%(10)$

$33.0 \%(29)$

$10.54 \pm 5.21$

$10.22 \pm 5.25$

$10.42 \pm 5.20$

All measures shown as mean $\pm \mathrm{SD}$ for continuous variables and $\%(\mathrm{~N})$ for categorical variables.

OGTT indicates oral glucose tolerance test; HOMA-IR, Homeostatic Model Assessment for Insulin

Resistance; HOMA2, Homeostatic Model Assessment 2. * $\mathrm{P}<0.05$ versus diet. 


\begin{tabular}{|c|c|c|c|c|c|c|c|c|c|}
\hline \multirow[b]{2}{*}{ Measures } & \multicolumn{3}{|c|}{ Liraglutide } & \multicolumn{3}{|c|}{ Sitagliptin } & \multicolumn{3}{|c|}{ Diet } \\
\hline & Baseline & 2 weeks & 14 weeks & Baseline & 2 weeks & 14 weeks & Baseline & 2 weeks & 14 weeks \\
\hline Weight, kg & $108.8 \pm 20.9$ & $108.3 \pm 21.0$ & $106.4 \pm 22.1 *+\dagger$ & $111.4 \pm 22.0$ & $111.0 \pm 22.6$ & $110.7 \pm 22.3 \div$ & $111.3 \pm 21.5$ & $109.9 \pm 21.4 *$ & $108.6 \pm 18.1 *$ \\
\hline Fasting glucose, mg/dL & $95.3 \pm 8.6$ & $84.3 \pm 7.9 * \dagger+$ & $85.2 \pm 7.3 * \dagger+$ & $97.6 \pm 10.0$ & $93.9 \pm 8.1$ & $96.6 \pm 5.6$ & $94.5 \pm 12.0$ & $92.4 \pm 11.3$ & $91.2 \pm 9.8 *$ \\
\hline Fasting insulin, $\mu \mathrm{U} / \mathrm{mL}$ & $22.7 \pm 16.8$ & $18.3 \pm 12.5 \dagger$ & $20.3 \pm 14.7$ & $23.3 \pm 14.4$ & $29.4 \pm 25.4 \div$ & $26.0 \pm 19.0 \div$ & $26.7 \pm 21.2$ & $19.7 \pm 16.5 *$ & $20.3 \pm 13.7 *$ \\
\hline HOMA-IR & $5.4 \pm 4.0$ & $3.9 \pm 2.8 * \dagger$ & $4.4 \pm 3.4 * \dagger$ & $5.5 \pm 3.3$ & $6.9 \pm 6.0 \%$ & $6.1 \pm 4.3 \%$ & $6.6 \pm 6.1$ & $4.8 \pm 4.6 *$ & $4.8 \pm 3.7 *$ \\
\hline Systolic BP, mmHg & $124.1 \pm 7.7$ & $122.9 \pm 6.3$ & $122.2 \pm 7.8 \%$ & $120.2 \pm 11.3$ & $117.5 \pm 11.3$ & $118.2 \pm 13.9$ & $127.7 \pm 8.3$ & $121.7 \pm 6.8 *$ & $119.7 \pm 11.1 *$ \\
\hline Diastolic BP, mmHg & $77.6 \pm 9.3$ & $78.3 \pm 7.7 \dagger$ & $77.7 \pm 7.1+t$ & $74.7 \pm 8.7$ & $72.3 \pm 7.8$ & $73.1 \pm 9.8$ & $77.9 \pm 7.0$ & $76.5 \pm 5.1$ & $74.8 \pm 8.3^{*}$ \\
\hline Heart rate, bpm & $64.9 \pm 7.5$ & $69.0 \pm 6.4 *+\dagger$ & $68.9 \pm 5.6 *+t$ & $67.2 \pm 9.0$ & $66.2 \pm 9.2$ & $65.9 \pm 8.5$ & $63.8 \pm 8.8$ & $63.2 \pm 9.5$ & $61.7 \pm 7.9$ \\
\hline PAI-1, U/mL & $20.2 \pm 9.2$ & $17.0 \pm 6.4$ & $16.9 \pm 6.4 * \dagger$ & $18.5 \pm 8.6$ & $16.9 \pm 6.5$ & $19.5 \pm 7.0 \%$ & $18.5 \pm 8.0$ & $19.4 \pm 7.5$ & $15.3 \pm 5.9 *$ \\
\hline P-selectin, ng/mL & $57.1 \pm 23.0$ & $56.6 \pm 24.1$ & $52.9 \pm 20.9$ & $52.3 \pm 25.3$ & $51.6 \pm 22.3$ & $51.8 \pm 19.5$ & $58.6 \pm 22.0$ & $57.5 \pm 28.4$ & $60.8 \pm 22.1$ \\
\hline UACR & $12.0 \pm 23.6$ & ND & $10.5 \pm 14.8$ & $7.9 \pm 7.6$ & ND & $9.2 \pm 10.7$ & $6.3 \pm 3.8$ & ND & $10.1 \pm 19.4$ \\
\hline \multicolumn{10}{|c|}{ Forearm Blood Flow Measures } \\
\hline Baseline diameter, mm & $3.35 \pm 0.51$ & $3.25 \pm 0.47$ & $3.33 \pm 0.55$ & $3.51 \pm 0.62$ & $3.47 \pm 0.63$ & $3.47 \pm 0.66$ & $3.41 \pm 0.67$ & $3.44 \pm 0.74$ & $3.40 \pm 0.71$ \\
\hline FMD, $\%$ & $10.54 \pm 5.21$ & $11.70 \pm 5.14$ & $12.01 \pm 6.18$ & $10.39 \pm 5.37$ & $12.18 \pm 4.56$ & $11.98 \pm 4.45$ & $10.22 \pm 5.25$ & $10.99 \pm 5.12$ & $10.73 \pm 4.80$ \\
\hline Fold change VTI & $7.99 \pm 2.48$ & $8.04 \pm 2.26$ & $8.48 \pm 2.36$ & $7.74 \pm 2.52$ & $8.36 \pm 2.72$ & $8.76 \pm 3.16$ & $7.70 \pm 2.16$ & $8.29 \pm 2.97$ & $9.41 \pm 1.31$ \\
\hline Pre-nitro diameter, mm & $3.39 \pm 0.51$ & $3.14 \pm 0.40$ & $3.20 \pm 0.42$ & $3.82 \pm 0.65$ & $3.38 \pm 0.80$ & $3.68 \pm 0.72$ & $3.46 \pm 0.77$ & $3.55 \pm 0.85$ & $3.88 \pm 0.86$ \\
\hline
\end{tabular}




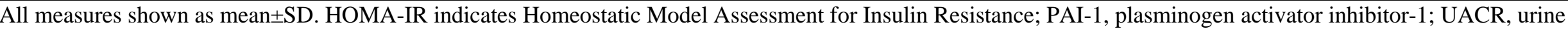

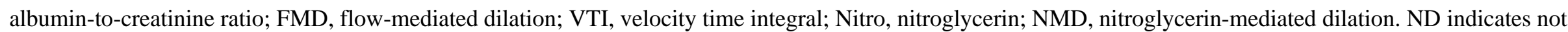
done. $* \mathrm{P}<0.05$ versus baseline; $\uparrow \mathrm{P}<0.05$ versus sitagliptin; $\uparrow \mathrm{P}<0.05$ versus diet. 
Table 3. Baseline Characteristics

\section{Subgroups}

\section{FMD\% $\quad$ FMD\%}

\section{$<$ Median > Median}

\section{Combined}

$\mathrm{N}=43 \quad \mathrm{~N}=42 \quad \mathrm{~N}=85$

Age, years

$48.3 \pm 10.9$

$51.8 \pm 10.7$

$50.0 \pm 10.9$

Gender

Male $32.6 \%(14)$ $31.0 \%(13)$

$31.8 \%(27)$

Female

$67.4 \%(29)$

$69.0 \%(29)$

$68.2 \%(58)$

Race

Asian

$4.7 \%(2)$

$0 \%(0)$

$2.4 \%(2)$

Black or African American

$7.0 \%(3)$

$19.0 \%(8)$

$12.9 \%(11)$

White

$88.4 \%(38) \quad 76.2 \%(32) \quad 82.4 \%(70)$

More Than One Race

$0 \%(0)$

$4.8 \%(2)$

$2.4 \%(2)$

Ethnicity

Hispanic or Latino

$4.7 \%(2)$

$4.8 \%(2)$

$4.7 \%(4)$

NOT Hispanic or Latino

$93.0 \%(40) \quad 95.2 \%(40) \quad 94.1 \%(80)$

Unknown / Not Reported

$2.3 \%(1)$

$0 \%(0)$

$1.2 \%(1)$

Weight, kg

$113.9 \pm 22.7 \quad 106.0 \pm 19.5 \quad 110.0 \pm 21.4$

BMI, $\mathrm{kg} / \mathrm{m}^{2}$

39.9 $\pm \mathbf{5 . 6 *} \quad 37.8 \pm 6.2 \quad 38.9 \pm 6.0$

Waist Circumference, $\mathrm{cm}$

$119.9 \pm 13.4 * \quad 113.7 \pm 11.6 \quad 117.0 \pm 12.9$

Hip Circumference, cm

$128.4 \pm 12.1 \quad 123.9 \pm 11.6 \quad 126.3 \pm 12.0$

Fasting blood glucose, $\mathrm{mg} / \mathrm{dL}$

$97.9 \pm 9.4 \quad 96.7 \pm 11.6 \quad 97.3 \pm 10.5$

Fasting insulin, $\mu \mathrm{U} / \mathrm{mL}$

27.0 $\pm 11.9 * \quad 18.7 \pm 12.8 \quad 22.2 \pm 13.0$

OGTT 2-hour blood glucose, mg/dL

$146.8 \pm 32.3 \quad 136.3 \pm 29.4 \quad 141.3 \pm 31.0$ 
medRxiv preprint doi: https://doi.org/10.1101/2022.02.23.22271434; this version posted February 25, 2022. The copyright holder for this preprint (which was not certified by peer review) is the author/funder, who has granted medRxiv a license to display the preprint in perpetuity. All rights reserved. No reuse allowed without permission.

HOMA-IR

HOMA2

Hemoglobin A1c, \%

Total cholesterol, mg/dL

Triglycerides, $\mathrm{mg} / \mathrm{dL}$

$\mathrm{HDL}, \mathrm{mg} / \mathrm{dL}$

LDL, mg/dL

Systolic blood pressure, $\mathrm{mmHg}$

Diastolic blood pressure, $\mathrm{mmHg}$

Heart rate, bpm

PAI-1, U/mL

FMD, \%
6.7 $\pm 3.0 *$

$4.3 \pm 2.7$

$5.3 \pm 3.0$

$0.52 \pm 0.23 *$

$0.35 \pm 0.23$

$0.42 \pm 0.24$

$5.7 \pm 0.3$

$5.7 \pm 0.3$

$5.7 \pm 0.3$

$185.4 \pm 30.1 \quad 190.3 \pm 44.3 \quad 187.9 \pm 37.8$

$120.4 \pm 54.2 \quad 133.0 \pm 62.2 \quad 126.7 \pm 58.3$

$45.8 \pm 10.7 \quad 46.0 \pm 9.9 \quad 45.9 \pm 10.3$

$114.9 \pm 26.8$

$117.8 \pm 36.2 \quad 116.4 \pm 31.8$

$123.4 \pm 8.1 \quad 124.8 \pm 9.8 \quad 124.1 \pm 9.0$

$\begin{array}{lll}76.0 \pm 8.9 & 77.8 \pm 8.7 & 76.9 \pm 8.8\end{array}$

$64.7 \pm 8.7 \quad 65.6 \pm 8.0 \quad 65.2 \pm 8.3$

$20.9 \pm 8.8 \quad 17.6 \pm 8.5 \quad 19.3 \pm 8.8$

$\mathbf{6 . 5 5} \pm \mathbf{2 . 8 1} * * \quad 14.39 \pm 3.94 \quad 10.42 \pm 5.20$

All measures shown as mean \pm SD for continuous variables and $\%(\mathrm{~N})$ for categorical variables. OGTT indicates oral glucose tolerance test; HOMA-IR, Homeostatic

Model Assessment for Insulin Resistance; HOMA2, Homeostatic Model Assessment

2; FMD, flow-mediated dilation. $* \mathrm{P}<0.05$ and $* * \mathrm{P}<0.001$ versus $\mathrm{FMD} \%$ greater than median. 


\section{Figure 1}
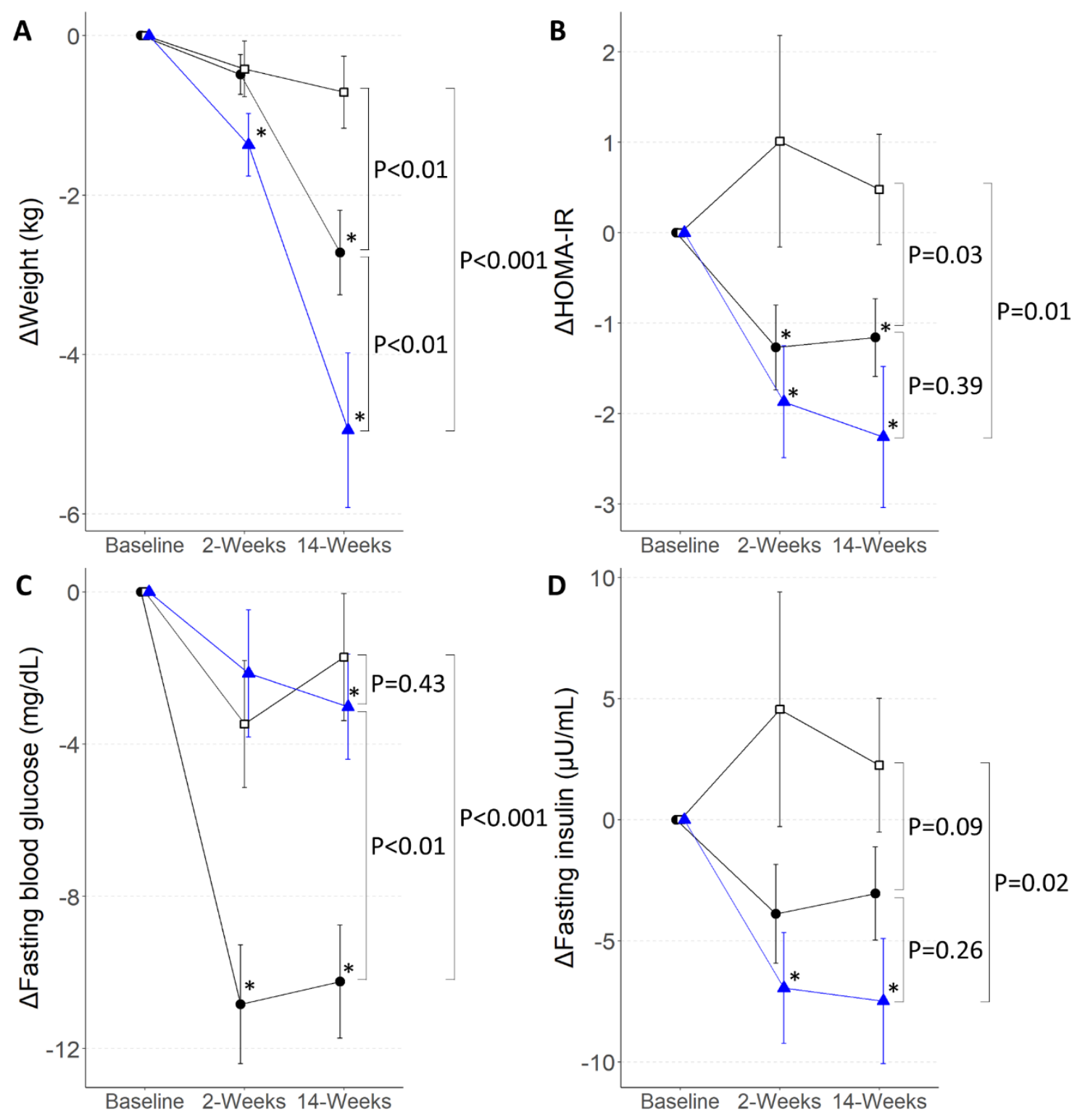

$\bullet$ Liraglutide $\square$ Sitagliptin $\wedge$ Diet

Figure 1. The Effect of Treatment on Weight, Fasting Blood Glucose, Fasting Insulin, and

Insulin Resistance. Plots show mean \pm SEM for (A) weight, (B) fasting blood glucose, (C) fasting insulin, and (D) HOMA-IR at 2 and 14 weeks of treatment as change from baseline. Asterisks indicate $\mathrm{P}<0.05$ for the change from baseline. Brackets indicate difference between 
medRxiv preprint doi: https://doi.org/10.1101/2022.02.23.22271434; this version posted February 25, 2022. The copyright holder for this preprint (which was not certified by peer review) is the author/funder, who has granted medRxiv a license to display the preprint in perpetuity.

All rights reserved. No reuse allowed without permission.

treatments at 14 weeks in regression model. HOMA-IR indicates Homeostatic Model

Assessment of Insulin Resistance. 


\section{Figure 2}
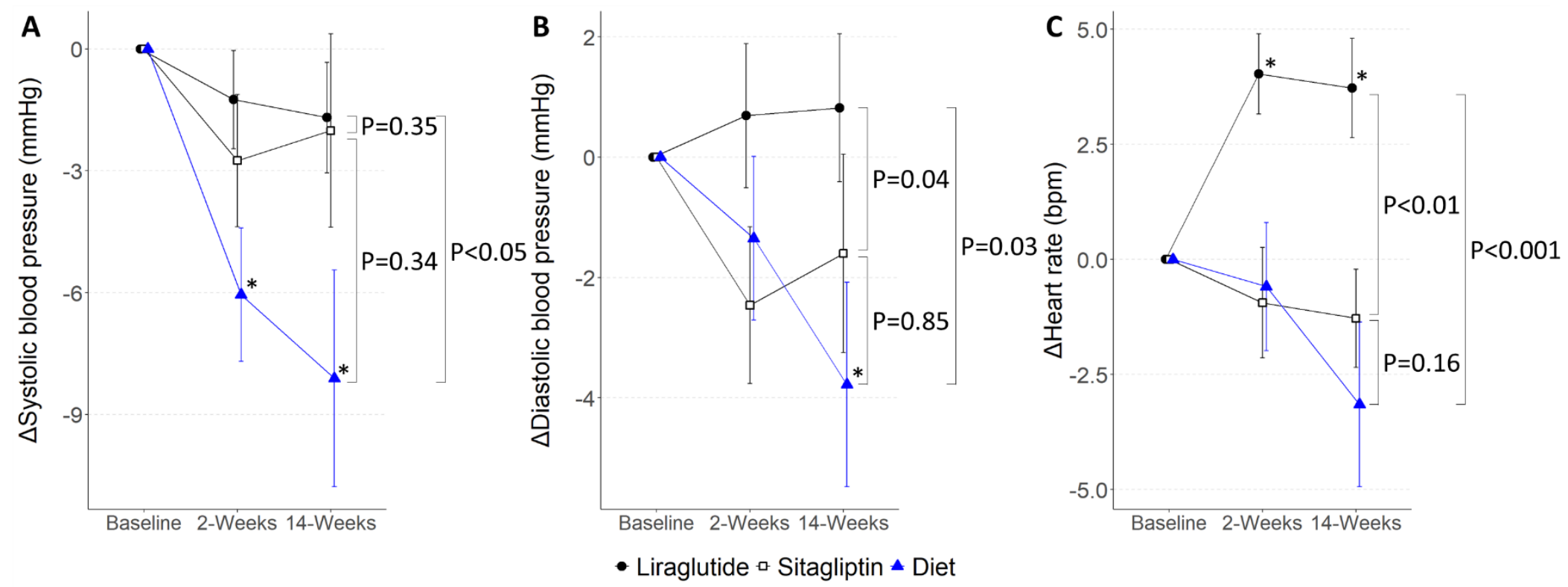

Figure 2. The Effect of Treatment on Hemodynamic Measures. Plots show mean \pm SEM for (A) systolic blood pressure, (B)

diastolic blood pressure, and $(\mathbf{C})$ heart rate at 2 and 14 weeks of treatment as change from baseline. Asterisks indicate $\mathrm{P}<0.05$ for the change from baseline. Brackets indicate difference between treatments at 14 weeks in regression model. 


\section{Figure 3}

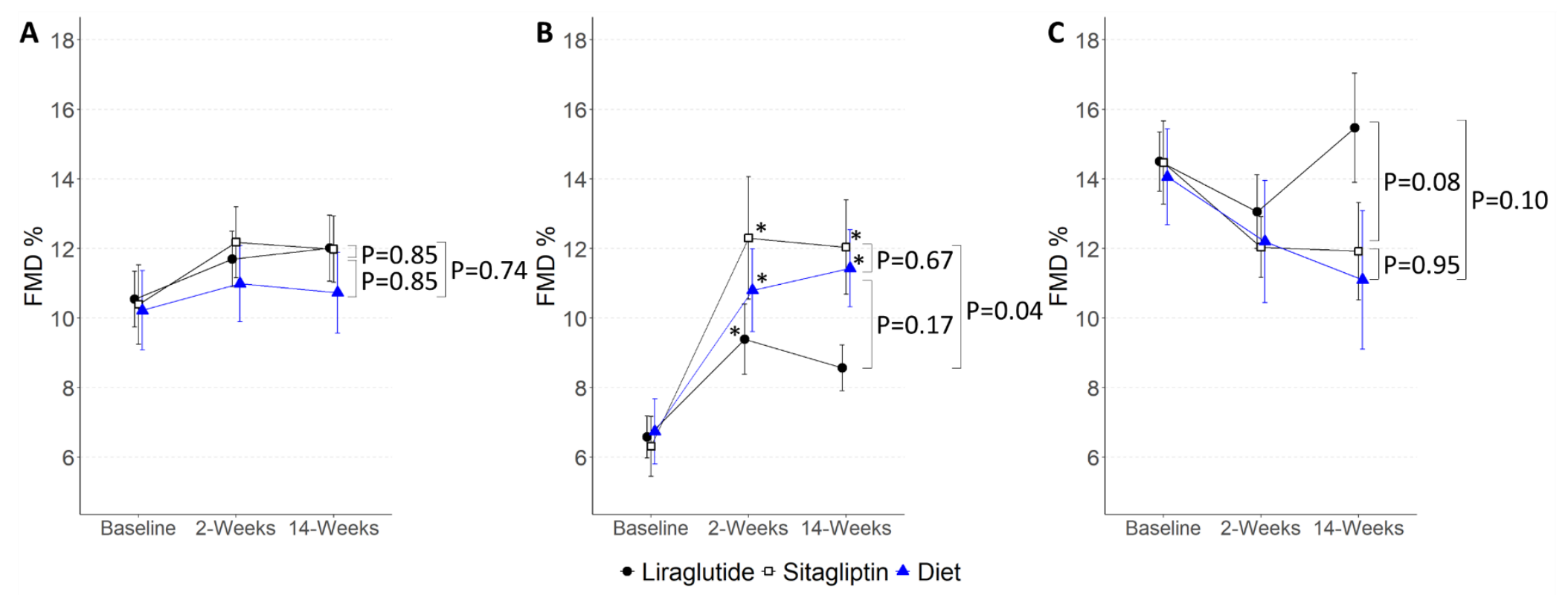

Figure 3. The Effect of Treatment on Flow-Mediated Dilation. Plots show mean \pm SEM for (A) FMD percent in entire cohort,

$(\mathbf{B}+\mathbf{C})$ FMD percent in subgroups of individuals with baseline FMD (B) below median or (C) above median for gender. Asterisks indicate $\mathrm{P}<0.05$ for the change from baseline. Brackets indicate difference between treatments at 14 weeks in regression model with gender as a covariate. FMD indicates flow-mediated dilation. 


\section{Figure 4}

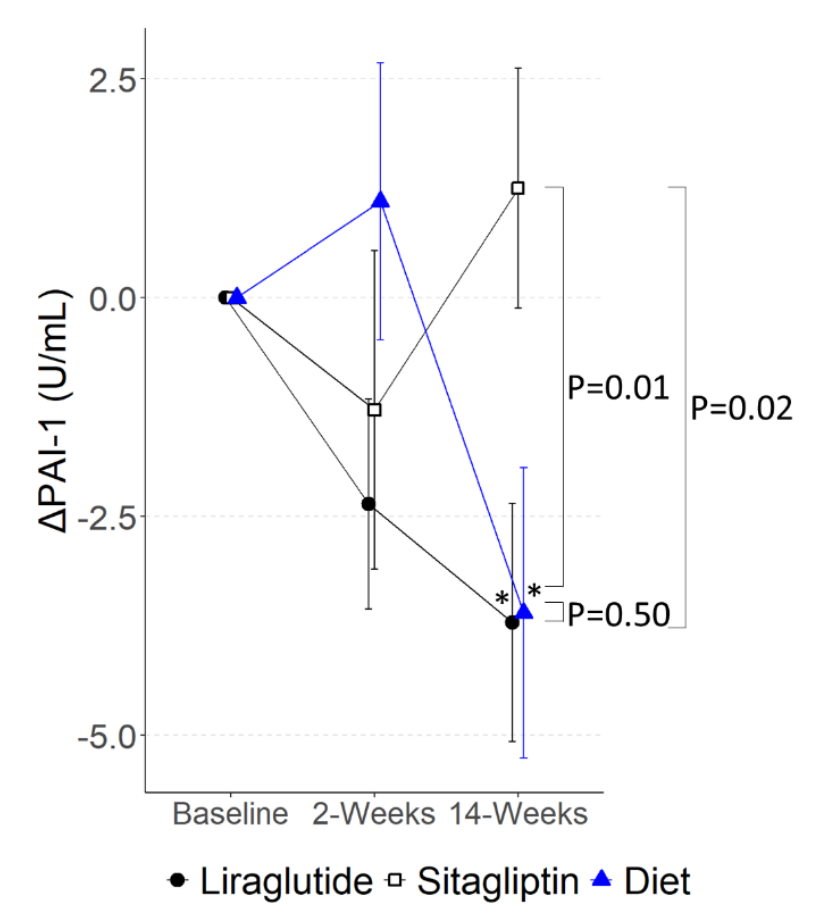

Figure 4. The Effect of Treatment on PAI-1. Plot shows mean \pm SEM for PAI-1 at 2 and 14 weeks of treatment as change from baseline. Asterisks indicate $\mathrm{P}<0.05$ for the change from baseline. Brackets indicate difference between treatments at 14 weeks in regression model. PAI-1 indicates plasminogen activator inhibitor-1. 


\section{Figure 5}
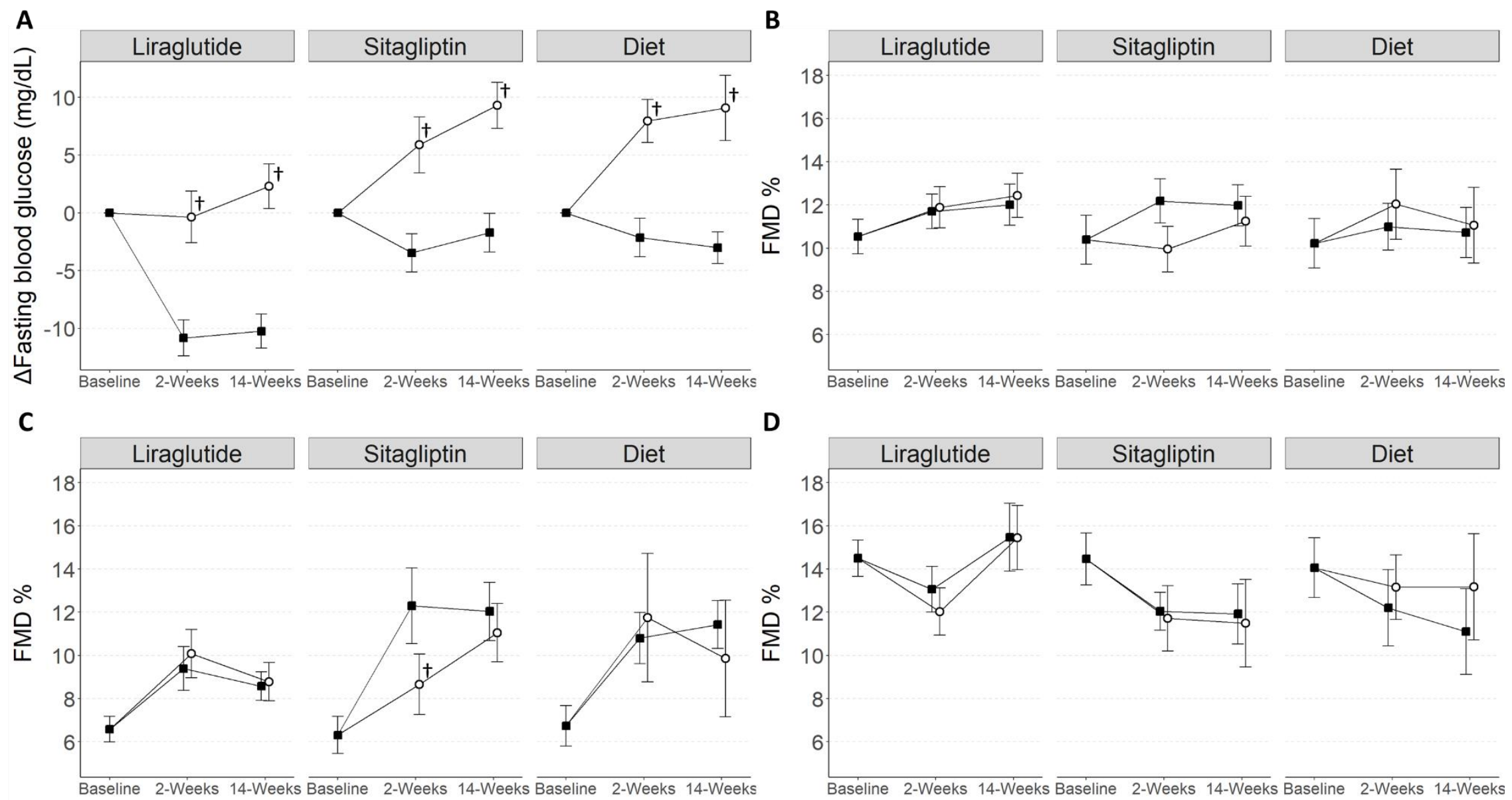

- Vehicle ○ Exendin 
Figure 5. The Effect of the GLP1R Antagonist Exendin (9-39) on Fasting Blood Glucose and FMD. Plots show mean \pm SEM for

(A) fasting blood glucose and (B-D) FMD percent. (A) Fasting blood glucose at 2 and 14 weeks of treatment as change from baseline.

(B) FMD percent in the entire cohorts; (C) in subgroup with baseline FMD percent below median; (D) in subgroup with baseline

FMD above median. Symbols $(\dagger)$ indicate $\mathrm{P}<0.05$ exendin versus vehicle in regression model. GLP1R indicated glucagon-like peptide-1 receptor. FMD indicates flow-mediated dilation. 
medRxiv preprint doi: https://doi.org/10.1101/2022.02.23.22271434; this version posted February 25, 2022. The copyright holder for this preprint (which was not certified by peer review) is the author/funder, who has granted medRxiv a license to display the preprint in perpetuity.

All rights reserved. No reuse allowed without permission. 